International Journal of English Literature and Social Sciences
Vol-6, Issue-3; May-Jun, 2021

\title{
Tribal verse and a different Worldview
}

Peer-Reviewed Journal

\section{Jyotismita Khataniar}

Sri Venkateswara College, University of Delhi, India

Received: 15 May 2021; Received in revised form: 08 Jun 2021; Accepted: 18 Jun 2021; Available online: 30 Jun 2021

(C)2021 The Author(s). Published by Infogain Publication. This is an open access article under the CC BY license

(https://creativecommons.org/licenses/by/4.0/).

\begin{abstract}
This paper presents an exploration of the loss of authentic Adivasi perspectives in mainstream literature. India has a large body of work on these peoples, but much of this romanticises them and fails to treat them as the inhabitants of a modern, industrial and globalising India. The tribal literature available in several non-mainstream languages has not been recognized because the tribal discourse, including folktales and songs, is mainly oral in nature. In addition to this, the communities which produce it tend to be far from urban jungles, and so their creative works have been largely overlooked. In this article, I discuss a popular extract from 'Painted Words' written by Indian linguist, G.N Devy which is featured in the text, 'Tribal Verse'. It provides arguments for alternative approaches of representing Adivasis, which become important to understand the Tribal worldview and their reasoning behind their several social and cultural traditions. This paper certainly is not an attempt to 'speak for' the marginalized languages. It is just a modest intention to explain why all human languages and linguistic creativity at large simply deserve greater respect.
\end{abstract}

Keywords-Adivasi, Tribal, Literature, Worldview, Language, Texts, Written, Oral.

\section{INTRODUCTION}

Totaling around 70 million, India has the world's largest population of tribal individuals (Chacko 2005, 16). Elen Turner writes that defining 'Tribal' or 'Adivasi' is problematic (Turner 2012, 329). Since 1950, the Indian government has designated certain groups as 'Scheduled Tribes', yet there is no official definition of this (Kulkarni 1994, 3073). Jaganath Pathy comments that it is now almost taboo for Indian social researchers to attempt to define the term as any definition would exclude some officially recognized Scheduled Tribes (2005, 36). The word 'Adivasi' is roughly equivalent to the English 'Tribal', yet claims to indigeneity in India are problematic as they beg the question of 'how far back in time must one go in order to establish the indigenous claims of a given social group' (Rodrigues and Game 1998, 2710). Different terms are used by the government, academics, the media, and the people themselves who are designated as such. For consistency, I use the term 'Adivasi' and 'Tribal' conversely in this article, though this does not reflect a judgment of the appropriateness of other terms.

India is rich with a diversity of faiths, arts, customs, races, traditions, and languages. Adivasi literature contributes to this diversity and it is literally rich and priceless in its native Tribal languages. The beginning of written Adivasi literature in India occurred in the early twentieth century when tribal communities came in contact with modern education in colonial days, especially, in the tribal areas of Jharkhand and the northeast. Since then, tribal literature in English and Hindi, and other Indian languages like Bengali, Oriya, Assamese, Marathi, etc. is on continuous progress and every year more than a hundred tribal books are being published in different languages. However, a lot of it is not written. Until recently, the tribal literature available in several non-mainstream languages has not been recognized or made available for a so-called 'mainland' Indian or global audience. One of the primary reasons for this is that the tribal discourse, including folktales and songs, is mainly oral in nature, which implies that it is not recorded textually.

The creative imagination in the tradition of orality does sometimes get expression in the written tradition. The writers of the tribes write down songs, prayers, and myths in their dialects or in Roman scripts. The area of ethnopoetics is a significant emerging field in literature. The ballads of Nandamma, Liamen, Thulasilamma and many others of the Irular tribe of Tamil Nadu, Karnataka, and Kerala are enriching experiences in ethno poetry. But, as stated above, these texts are not accessible to a global audience due to language barriers.

In addition to this, the communities which produce it tend to be far from urban jungles, and so their creative works have been largely overlooked. The tribal communities have continued their creative literary expeditions since 
time immemorable but, because the tribal communities were far from the centers of power, their literature, like they themselves, was largely ignored. Even today, Tribal literature is being produced in thousands of indigenous languages but we know little about it.

Due to the dearth of knowledge about Tribal literature, the perspective of the indigenous communities on the world around them is difficult to be understood. Texts on these communities from an outsider's perspective are available but much of this romanticizes them and fails to treat them as the inhabitants of a modern, industrial and globalizing India.

To get an understanding of the Adivasi worldview, I will refer to an extract from 'Painted Words' by G.N Devy,which is a part of the text called 'Tribal Verse'. Devy, a literary critic, and linguist who was formerly a professor of English at Maharaja Sayaji Rao University of Baroda, is also the Founder Director of the Tribal Academy at Tejgarh, Gujarat. He is the Director of Sahitya Akademi's Project on Literature in Tribal Languages and Oral Traditions. The author, through his essay 'Tribal Verse' makes an attempt to familiarise people with some facets of the enormous wealth of oral tribal literature.

The paper is a modest attempt in the direction of understanding what G.N Devytries to highlight through his writing. This work is theoretical in nature involving the study of the above-mentioned tribal literature text. This research work that broadly comes under the tribal literary studies is an attempt to examine the literary traditions of tribal communities.

\section{TRIBAL VERSE AND UNTOUCHED WORLDS}

The People's Linguistic Survey of India, a massive survey of languages, which Devy launched had its genesis when he was in his 20s, as a research student reading the 1971 census. He found that while the 1961 census recorded some 1,652 mother tongues, the 1971 census listed only 108 ,the 109th item reading 'All Others'. Those two words influenced him to look in-depth into the category.

This prompted questions from the tribal perspective. Devy wanted to know if there was something in these Tribal languages that kept them strong and kept their communities undestroyed and non-colonized. This question arose from a historical context. Wherever English went - Canada, the U.S., Australia, New Zealand - it destroyed native languages, but in India, tribal communities continued to talk in their languages, as did 'mainland' Indians.

There were no books to answer these questions. Linguistic anthropology at the time of the Survey described communities with theoretical apparatus, but not in terms of a lived historical experience. Devy spoke in an interview with The Hindu, "Anthropology granted tribals only their sociology, and denied them their history." In the pursuit of finding answers to these questions, G.N Devy researched and produced valuable texts, 'Painted Words' being one of the most remarkable ones, which help us analyze the importance of preserving Adivasi literature.

G.N Devy brings out the importance of the oral literary tradition of India by referring to the richness of the tribal literary works, in the form of stories, songs, and poems, that have been handed down from one generation to the other orally.

The writing in 'Tribal Verse' begins with the abovementioned extract from the essay by G.N. Devy in which he discusses the need to nurture a space and formulate an innovative approach for the study of tribal literature within the framework of canonized written texts. He argues for a new method to identify and read literature in which orality is not dismissed as casual utterances in different dialects but taken seriously into account. This argument seems relevant and fair because a vast number of Indian languages have yet remained only spoken, with the result that literary compositions in these languages are not considered 'literature'.

"They are a feast for the folklorist, anthropologist and linguist, but to a literary critic they generally mean nothing." (Devy 2002, 12)

Similarly, several nomadic Indian communities are now fragmented and spread over long distances but continue to subsist as communities because they are bound by their oral epics. The wealth and diversity of these works is so huge that one sees their neglect with a sense of pure embarrassment.

This text attempts to understand the literary imaginations of these communities whose speech traditions face the prospect of forced aphasia. It features representative works from languages that have remained largely spoken and are just beginning to be written; languages that have slowly started acquiring scripts and developing written arrangements of literature, dialects that are fast perishing because they are on the boundaries of the main languages, or from peoples that have continued to stay outside the caste fold of Indian society.

Apart from G.N Devy's writing, this text encompasses two other songs - one sung on the occasion of childbirth by the Munda tribals and the other on the occasion of death by the Kondh tribals. The third verse is a chanting in the ceremonial religious language of the Adi tribe, not the same as their language of dialog. Although this is simply a small representation of a treasure of Tribal/Adivasi songs, it points towards the immense diversity that exists amongst tribal groups. Unavoidably predisposed by their very specific historical, cultural, and geographical positions, tribal societies continue to retain and reproduce their idiosyncratic traditions which usually find expression through their different languages.

G.N Devy elaborates on several instances of how the Adivasi is different from the ones who do not belong to this vast categorization. In regard, we can focus on a few. Devy points out that the tribals show very little interest in 
amassing capital or in using labour as a manoeuvre to gather more capital. Their perspective on the world is not as economical. It rests on the links between nature, human beings, and God. Their life choices are mostly based on intuition than reason, and this makes their worldview rather different from the mainstream Indian population. The tribal communities consider the space around them more sacred than secular, and their sense of time is personal rather than objective. From this, we can understand that the tribal imagination is not only radically different from that of modern Indian society, but it is also dynamic in its own ways. The tribal imagination, in simple words, acknowledges amalgamation of numerous planes of existence and levels of time in a natural way.

To further understand how tribal artists come up with their art and interpret it, it is important to make a distinction between imagination and memory. It is often said that tribal artists work more on the basis of their racial and sensory memory than on the basis of a cultivated imagination. The tribal mind features a more acute sense of time than a sense of space. Somewhere along with the history of human civilization, tribal communities seem to have realized that domination over territorial space was not their area of interest. And likewise, they seem to have turned almost obsessively to gaining domination over time. This urge is authenticated in their ritual of communicating with their deceased ancestors. Year after year, tribals in many parts of India revere terracotta or carved-wood objects representing their ancestors. One of the main characteristics of tribal arts is thus, their distinct manner of constructing space and imagery, which might be described as 'hallucinatory'. In both oral and visual sorts of representations, tribal artists seem to interpret verbal or pictorial space as demarcated by a particularly flexible 'frame'. The margins between art and non-art become nearly imperceptible.

Another important point that Devy brings to our notice is that non-tribals usually fail to understand that all of India's tribal communities are basically bilingual. Bilingual communities have an innate capacity to assimilate outside influences, and thus, a highly evolved mechanism for responding to the non-tribal world becomes important to be developed. Tribal oral stories and songs engage with bilingualism in such a complex style that a linguist who is not attentive to this intricacy is in danger of dismissing the tribal languages altogether as dialects of the subcontinent's major tongues.

\section{CONCLUSION}

From the discussion above, we can say that it is time we realize that unless we modify the established notion of literature as something written, we will silently witness the decline of various Indian oral traditions. In actuality, literature is a lot more than writing and it is a reminder, necessary for our times.
Most of our oral literature faces the hazard of being lost to stupor and oblivion because it neither enjoys institutionalized backing nor it is preserved by intergenerational transfer anymore. It has been observed currently, that the vast amount of folklore and oral literature is not passed on to the younger generation for the reason thatthere are socio-economic burdens and thus, faces the danger of being lost to us. Although writing systems and scripts are not new to us, a substantial number of languages remain unwritten, and thus, these are difficult to be incorporated in formal education. However, for these languages are rich in all the genres of folk literature, it is important to structure out methods of preservation that go beyond conventional modes. These must preserve indigenous and traditional knowledge of the society, environment, and history. According to Devy, knowledge can only be expanded at the margins of experience, which is why he chose to study bhasha over the poetics of Sanskrit, and Adivasi literature over that of the dominant castes. It is also why he argues that each dialect, spoken by however many people in whichever part of the country, needs urgently to be preserved. Devy's work in the last two decades has been centered on just such a mission.

Considering the vast quantity of oral literature available in the languages of the seven language families of India, it is desirable to document, analyze, digitize and archive the massive wealth of the country, in some way or the other. Such an attempt will add tremendously valuable materials to our literary histories and elements to our literary criticism.

\section{REFERENCES}

[1] "About the Centre for Oral and Tribal Literature." Sahitya Academy, 2021, sahitya-akademi.gov.in/aboutus/cotlit.jsp.

[2] Asha, S.R. Aldin, "Global Journal of Human Social Science Linguistics and Education", Cultural Translatability and Untranslatability of the Folk Songs in Bama's Sangati, Volume 13, Issue 6, Version 1.0, Global Journals, Inc (USA), 2013, Web

[3] Chacko, Pariyaram M., ed. 2005. Tribal communities and social change. New Delhi: Sage Publications

[4] Dalton, E. T. Tribal History of Eastern India. Delhi: Cosmos Publications, 1973.

[5] Devy, G. (2003). Painted Words: An Anthology of Tribal Literature. Penguin Books India.

[6] Elen Turner (2012) An unfinished story: The representation of adivasis in Indian feminist literature, Contemporary South Asia, 20:3, 327-339, DOI: 10.1080/09584935.2011.649715

[7] Griffin, P. (2018, March 11). When a language dies, something irreplaceable dies: Ganesh N. Devy. The Hindu. https://www.thehindu.com/society/when-a-language-diessomething-irreplaceable-dies-says-ganesh-ndevy/article22998792.ece

[8] Kulkarni, Sharad. 1991. Distortion of census data on scheduled tribes. Economic and Political Weekly 26, no. 5: 205-8. 
[9] Kumar, S. P., Chauhan, V. S., Prakash, B., \& University of Delhi. Department of English. (2005). Cultural Diversity Linguistic Plurality and Literary Traditions in India. Macmillan Publishers.

[10] Painted Words: An Anthology of Tribal Literature by G. N. Devy (2002-01-01). Penguin USA (P), 2021.

[11] Pathy, Jaganath. 2005. Tribe, region, and nation in the context of the Indian state. In Tribal communities and social change, ed. Pariyaram M. Chacko, 30-45. New Delhi, Thousand Oaks and London: Sage Publications.

[12] Rodrigues, Eddie, and John Game. 1998. Anthropology and the politics of representation. Economic and Political Weekly 33, no. 42/43: 2709-14.

[13] "The Centre Cannot Hold: How G. N. Devy Challenges Our Concept of Knowledge". vikalpsangam.org. vikalpsangam.org. Retrieved 26 February 2021.

[14] Tribal Verse. (2005). In Cultural Diversity Linguistic Plurality and Literary Traditions in India (pp. 71-80). Macmillan Publishers India. 